\title{
Virtual vs. Conventional Practicum in Pharmacology: Students' Perspectives
}

\author{
Riana Rahmawati $^{1, *}$ Isnatin Miladiyah $^{1}$, Muflihah Rizkawati ${ }^{1}$, Marlina Anggraeni ${ }^{1}$ \\ ${ }^{1}$ Pharmacology Department, Faculty of Medicine, Universitas Islam Indonesia \\ *Corresponding author. Email: riana.rahmawati@uii.ac.id
}

\begin{abstract}
The coronavirus disease (COVID-19) pandemic has significantly affected the medical education process, in both clinical and preclinical years. This study compared students' perspectives of the pharmacology practicum conducted in 2019 (pre-pandemic, conventional) and 2020 (virtual, via the Zoom platform). Secondary data used in this study were derived from questionnaires completed by students enrolled in two courses: a) Infection and b) Health Problems in Paediatrics. A questionnaire comprising 14 Likert-scale questions and two open-ended questions was used to assess students' perspectives of co-teachers' performance in small-group discussion and the quality of practicum learning. An independent $t$ test was used to compare the responses. The responses to open-ended questions in the questionnaire were analysed descriptively. We assessed 191 and 344 questionnaires collected in the years 2019 (before the pandemic) and 2020 (during the pandemic), respectively. The mean score of co-teacher performance in the conventional practicum was 3.997 out of 4.000 , which was higher than the score for the virtual practicum (3.841 out of 4.000, $<<0.001$ ). Most students in both groups responded "very good" (score 4) to the question about whether the practicum learning objectives could be achieved. The mean score for all items was $>3.600$. However, some challenges during practicum in the pandemic era were identified; these related to both practical (e.g., unstable internet connection) and substantive (e.g., inadequate prior knowledge of medications) aspects. Students perceived that both the conventional and virtual practicum were performed adequately to achieve the learning objectives. Despite the perceived good practice in virtual practicum, students preferred hands-on experience in pharmacology training.
\end{abstract}

Keywords: pharmacology, virtual learning, COVID-19.

\section{INTRODUCTION}

The coronavirus-19 disease (COVID-19) pandemic has significantly impacted the education system at all levels, and universities have had to manage the change from the face-to-face education to online learning [1]. Indonesia, a developing country in South-East Asia, has 4,599 universities across 33 provinces (https://pddikti.kemdikbud.go.id/). To anticipate the spread of COVID-19, the Indonesian government launched Circular Letter No. 36952, which focused on the implementation of online learning for all levels of education in Indonesia, including universities [2]. Universitas Islam Indonesia (UII) responded immediately to the government recommendation and began online learning in March 2020.
The Faculty of Medicine UII implemented a problembased learning (PBL) approach, which is defined as "an instructional (and curricular) learner-centered approach that empowers learners to conduct research, integrate theory and practice, and apply knowledge and skills to develop a viable solution to a defined problem" [3]. The curriculum for undergraduate medical students in UII comprises 24 courses (also known as blocks) completed within 4 years. Learning activities within each course comprise tutorials (the core element of PBL), expert lectures, clinical skill laboratories, assignments, and practicums. Consistent with its learning objectives, each course involves input from the relevant departments such as pharmacology, anatomy, and internal medicine. The Faculty of Medicine UII has 22 departments in total. 
Practicum in pharmacology is designed to provide practical sessions for students. During the COVID-19 pandemic in 2020, the practicum was designed to be presented virtually. Previous studies, particularly in developing countries, have identified some obstacles to conducting ideal online learning [1][4]. For example, a study in Serang, Indonesia, reported that $32 \%$ of students perceived difficulties in understanding materials included in online learning [5].

This aims of this study were to describe students' perspectives on the quality of pharmacology practicum learning and co-teachers' performance, and to compare these perceptions between virtual and conventional practicum experiences. Feedback and suggestions from the students about improving the pharmacology practicum were also surveyed.

\section{METHODS}

This observational study used data derived from routine program evaluation in the Department of Pharmacology, Faculty of Medicine UII. The data were divided into two sets obtained from the students who completed their pharmacology practicum in the year 2019 (conventional practicum, pre-pandemic group) and those who completed their practicum in the year 2020 (online via the Zoom platform, pandemic group). The pharmacology practicum is a part of the learning activities in the courses. The two courses selected in this study were Infection and Health Problem in Paediatrics. These courses were chosen because data from both the pre-pandemic and pandemic groups were available.

All enrolled students in the two selected courses who attended the practicum sessions were asked to complete an evaluation questionnaire immediately after a practicum sessions ended. In the virtual practicum, the link to the questionnaire was provided in the last 5 minutes of the Zoom class. We included all completed questionnaires from the students.

The questionnaire comprised 14 Likert-scale questions and two open-ended questions. The first seven questions assessed the co-teachers' performance. Coteachers or assistants facilitated small-group discussion in the practicum to deepen the students' understanding of the topic studied. The students were asked about their perspectives of the following items: the co-teachers' ability to explain the material, the co-teachers' ability to respond to students' questions and to motivate students, the suitability of the material discussed in the smallgroup discussions, and co-teachers' discipline, dedication, and actions as a role model. The questions about the quality of practicum learning comprised the following items: achievement of learning objectives, the role of the practicum in supporting the courses' learning objectives, time allocation, assessment methods, and availability of adequate facility and resources for the practicum. The responses to these questions ranged from 1 to 4 ( 1 = very bad, $2=$ bad, $3=$ good, and $4=$ very good). The open-ended questions explored the students' perspectives of the constraints experienced during the practicum and their suggestions for further improvement.

Quantitative data from the questionnaire were analysed using IBM SPSS Statistics (version 21). We used an independent $t$ test to compare the mean practicum evaluation scores for each response item. Responses on the open-ended questions were analysed descriptively.

\section{RESULTS}

We analysed 191 and 344 questionnaires collected from students in the conventional and virtual practicum groups, respectively. The mean co-teacher performance score for the conventional practicum was 3.999 out of 4 , which was higher than that for the virtual practicum (3.841, $\mathrm{p}<0.001)$. A similar pattern was found for the assessment of the quality of practicum learning; the mean of scores were 3.998 and 3.780 for the conventional and virtual practicum, respectively. Despite the statistically significant differences, most students rated all items in the questionnaire as "very good" (score of 4)" or "good" (score of 3 ) in both conventional and virtual practicums.

Tables 1 and 2 present a comparison between the two groups for each item in the questionnaire. The conventional practicum group gave higher scores for all items $(\mathrm{p}<0.001)$. However, each item of performance in the virtual practicum group had a mean of score $>3.500$. The two lowest mean scores related to the adequacy of practicum materials (3.602) and time allocation of practicum (3.610).

Table 1 Comparison of means scores for co-teachers' performance during conventional vs. virtual pharmacology practicum

\begin{tabular}{|c|c|c|c|}
\hline Item & $\begin{array}{l}\text { Conventional } \\
\text { practicum } \\
2019\end{array}$ & $\begin{array}{l}\text { Virtual } \\
\text { practicum } \\
2020\end{array}$ & $\mathrm{p}^{* *}$ \\
\hline $\begin{array}{l}\text { Ability to explain the } \\
\text { materials discussed in the } \\
\text { practicum }\end{array}$ & 4.000 & 3.817 & $<0.001$ \\
\hline $\begin{array}{l}\text { Ability to respond to the } \\
\text { students' questions }\end{array}$ & 3.995 & 3.808 & $<0.001$ \\
\hline $\begin{array}{l}\text { Ability to motivate } \\
\text { students to complete their } \\
\text { practicum tasks }\end{array}$ & 4.000 & 3.831 & $<0.001$ \\
\hline $\begin{array}{l}\text { Discipline and time } \\
\text { management skills }\end{array}$ & 4.000 & 3.843 & $<0.001$ \\
\hline $\begin{array}{l}\text { Dedication to facilitating } \\
\text { student learning }\end{array}$ & 3.995 & 3.858 & $<0.001$ \\
\hline $\begin{array}{l}\text { Role model and Islamic } \\
\text { values }\end{array}$ & 4.000 & 3.820 & $<0.001$ \\
\hline $\begin{array}{l}\text { Suitability of the material } \\
\text { discussed in the small- } \\
\text { group discussions }\end{array}$ & 4.000 & 3.907 & $<0.001$ \\
\hline
\end{tabular}


Table 2 Comparison of mean scores for students' perspectives of the quality of practicum learning (conventional vs. virtual practicum)

\begin{tabular}{|c|c|c|c|}
\hline Statements & $\begin{array}{l}\text { Conventional } \\
\text { practicum } \\
2019\end{array}$ & $\begin{array}{c}\text { Virtual } \\
\text { practicum } \\
2020\end{array}$ & $\begin{array}{c}\mathrm{p} \\
\text { value* }\end{array}$ \\
\hline $\begin{array}{l}\text { Practicum learning } \\
\text { objectives could be } \\
\text { achieved }\end{array}$ & 3.995 & 3.860 & $<0.001$ \\
\hline $\begin{array}{l}\text { Practicum } \\
\text { activities increase } \\
\text { the students' } \\
\text { understanding in } \\
\text { the topic }\end{array}$ & 4.000 & 3.831 & $<0.001$ \\
\hline $\begin{array}{l}\text { Learning } \\
\text { objectives are } \\
\text { practical and } \\
\text { integrated }\end{array}$ & 4.000 & 3.831 & $<0.001$ \\
\hline $\begin{array}{l}\text { Time allocation for } \\
\text { the practicum is } \\
\text { adequate }\end{array}$ & 3.995 & 3.610 & $<0.001$ \\
\hline $\begin{array}{l}\text { Assessment } \\
\text { method used in the } \\
\text { practicum is } \\
\text { objective }\end{array}$ & 4.000 & 3.793 & $<0.001$ \\
\hline $\begin{array}{l}\text { Facilities to } \\
\text { conduct the } \\
\text { practicum are } \\
\text { adequate (class, } \\
\text { sound system, } \\
\text { computer, internet) }\end{array}$ & 4.000 & 3.695 & $<0.001$ \\
\hline $\begin{array}{l}\text { Practicum } \\
\text { materials are } \\
\text { adequate }\end{array}$ & 3.995 & 3.602 & $<0.001$ \\
\hline
\end{tabular}

The students were not required to respond to the two open-ended questions; that is, the questions were optional and the students could choose not to answer. A higher percentage of students in the virtual practicum group answered the qualitative questions (Table 3 ).

Table 3 Students' perspectives on the quality of practicum learning

\begin{tabular}{|l|c|c|c|}
\hline \multicolumn{1}{|c|}{ Questions } & $\begin{array}{c}\text { Conventional } \\
\text { practicum } \\
2019 \\
(\mathrm{~N}=191)\end{array}$ & $\begin{array}{c}\text { Virtual } \\
\text { practicum } \\
2020\end{array}$ & $\begin{array}{c}\text { Total } \\
(\mathrm{N}=535)\end{array}$ \\
\hline $\begin{array}{l}\text { Please tell us your } \\
\text { concerns regarding } \\
\text { the practicum } \\
\text { sessions (e.g., } \\
\text { obstacles } \\
\text { experienced during } \\
\text { the practicum) }\end{array}$ & $6(3.1)$ & $\mathrm{n}(\%)$ & $\mathrm{n}(\%)$ \\
\hline $\begin{array}{l}\text { Please provide your } \\
\text { suggestions for } \\
\text { improving the } \\
\text { practicum }\end{array}$ & $8(4.2)$ & $172(50)$ & 178 \\
\hline
\end{tabular}

Among the 178 responses to the first open-ended question, $51(28.65 \%)$ were positive responses such as "it's good already", "no problem", and "well done". Concerns regarding the practicum sessions gathered from the questionnaire included the time allocation (39, $21.91 \%)$, internet connection $(32,17.98 \%)$, and practicum materials $(39,21.91 \%)$. A lack of prior knowledge, a large number of medications needing to be studied, and the limited time for small-group discussion with the co-teachers were substantive obstacles identified in the questionnaire. Seventeen of 172 responses in the virtual practicum group noted "the online system" as the main constraint for optimal practicum learning.

Consistent with the abovementioned responses, suggestions from the students addressed aspects that need to be maintained (good practicum practice) and some specific advice for improving the practicum. The practicum sessions that included small-group discussion (facilitated by co-teachers) was received well because it helped the students deepen their understanding of the practicum topics. Other positive feedback included, "the practicum was well organised", "well done, strict time allocation made the practicum efficient", "the next practicum should be like this", and "it was fun". However, some students explicitly suggested that "going offline" represented their strongest desire to return to face-to-face practicum sessions.

Specific suggestion to improve the quality of practicum learning could be categorised into material preparation, time allocation and internet connection. Students suggested that improvements are needed in the preparation and provision of materials. They also mentioned the need for the exercise items to be made available before the relevant practicum session. Students also expressed a desire to access the answer keys and written explanations about the items discussed during practicum session. Despite the students' appreciation of the co-teacher-guided discussions, they expressed concern about the balance between the time allocated and the number of exercise items provided. Given the problems related to the poor internet connection, students asked for greater focus on ensuring that co-teachers and students have excellent internet connection. Some students noted annoying moments when their co-teacher had trouble joining the Zoom platform.

\section{DISCUSSION}

The virtual pharmacology practicum was undertaken at short notice because of the COVID-19 pandemic. The findings of our study show that students perceived the virtual practicum as generally satisfactory. The responses analysed in this study reflected mainly good co-teacher performance and good quality of practicum learning. These positive findings reflect the faculty's efforts to achieve the learning objectives when online learning is an unavoidable option [1]. 
Implementing effective online practicum sessions has some challenges that need to be addressed [6][7]. Technical problem during online classes (e.g., poor connection) is a crucial barrier and can significantly reduce students' satisfaction [8][9]. Baticulon et al. (2020) categorised the barriers to adapt online learning into technological, individual, domestic, institutional, and community barriers [10]. Therefore, the implementation of online learning should be prepared carefully to meet the students' needs and faculty expectations [11].

The responses to the questions highlighted some students' preferences to return to conventional practicum sessions. Quantitatively, the mean scores for practicum and co-teacher performance were higher for the conventional practicum than for the virtual practicum. Preference to face-to-face education was also reported in a study among Pakistani medical students [12]. A study in Uganda reported medicine and nursing students perceived online learning reduced the quality of knowledge attained and preferred blended learning that combines classroom and online learning [4]. These findings reflect the students' concerns about some of the challenges in online education that need to be addressed.

The pharmacology practicum was designed to provide learning activities that teach practical and experiential skills to students [6]. During the practicum sessions, students were introduced to selected medications, their formulations, dosages, and mechanisms of actions. In the third-year courses (e.g. Health Problems in Paediatrics), selected cases and medications were used to teach students about filling a prescription. The lack of hands-on experience during the virtual practicum might alter the students' understanding of the materials [6][13].

The unprecedented situation amid the COVID-19 pandemic forced the educators to organize the materials using a new mode of delivery [14]. Educators should improve their capacity to adapt in the online environment, including methods for maintaining interactions with students, the opportunities for which have decreased significantly with online learning [12] [15]. Self-regulated learning is important to the success of online learning [16], and the faculty should facilitate resources that support students' independent learning. A study in Lebanon identified effective engagement strategies in higher education as collaborative flipped teaching, in-class group work, moderation of discussions, and collaborative presentations [17].

\section{CONCLUSION}

Students perceived that both the conventional and virtual practicums were performed adequately to achieve the learning objectives. Despite the good scores for their perceptions of the virtual practicum, students prefer hands-on experience in pharmacology training.

\section{AUTHORS' CONTRIBUTIONS}

RR designed the study, analysed the data, and prepared the manuscript draft. IM and MR were actively involved in the data analysis and manuscript drafting. MA contributed to the study design and provided significant contribution to the data collection and data analysis.

\section{ACKNOWLEDGMENTS}

We thank all students involved in this study. We appreciate the Faculty of Medicine Universitas Islam Indonesia for providing a grant to complete this study.

\section{REFERENCES}

[1] S. Tadesse and W. Muluye, The impact of COVID-19 pandemic on education system in developing countries: A review, Open J. Soc. Sci., vol. 8, no. 10, pp. 159-170, 2020.

[2] Ministry of Education and Culture, Circular Letter No.36952 about online learning and working at home to anticipate the Covid-19 spread, 2020.

[3] J. R. Savery, Overview of problem-based learning: Definitions and distinctions, Essent. readings Probl. Learn. Explor. extending Leg. Howard S. Barrows, vol. 9, pp. 5-15, 2015.

[4] R. Olum et al., Medical education and elearning during COVID-19 Pandemic: Awareness, attitudes, preferences, and barriers among undergraduate medicine and nursing students at Makerere University, Uganda, $J$. Med. Educ. Curric. Dev., vol. 7, p. 2382120520973212, 2020.

[5] D. Surani and H. Hamidah, students perceptions in online class learning during the COVID-19 pandemic, Int. J. Adv. Sci. Educ. Relig., vol. 3, no. 3, pp. 83-95, 2020.

[6] M. M. Mitchell and C. Delgado, Online learning: Advantages and challenges in implementing an effective practicum experience, Open J. Nurs., vol. 4, no. 6, p. 379, 2014

[7] M. H. Rajab, A. M. Gazal, and K. Alkattan, Challenges to online medical education during the COVID-19 pandemic, Cureus, vol. 12, no. 7, 2020.

[8] M. Adnan and K. Anwar, Online learning amid the COVID-19 pandemic: Students' 
perspectives., Online Submiss., vol. 2, no. 1, pp. 45-51, 2020.

[9] C. Coman, L. G. Țîru, L. Meseșan-Schmitz, C. Stanciu, and M. C. Bularca, Online teaching and learning in higher education during the coronavirus pandemic: Students' perspective, Sustainability, vol. 12, no. 24, p. 10367, 2020.

[10] R. E. Baticulon et al., Barriers to online learning in the time of COVID-19: A national survey of medical students in the Philippines, medRxiv, 2020 .

[11] H. H. Muljo, A. S. Perbangsa, and B. Pardamean, Online learning prototype for higher education, in 2017 International Conference on Information Management and Technology (ICIMTech), 2017, pp. 49-53.

[12] S. Abbasi, T. Ayoob, A. Malik, and S. I. Memon, Perceptions of students regarding Elearning during Covid-19 at a private medical college, Pakistan J. Med. Sci., vol. 36, no. COVID19-S4, p. S57, 2020.

[13] K. D. Karpa and K. E. Vrana, Creating a virtual pharmacology curriculum in a problem-based learning environment: one medical school's experience, Acad. Med., vol. 88, no. 2, pp. 198 205, 2013.

[14] A. Aristovnik, D. Keržič, D. Ravšelj, N. Tomaževič, and L. Umek, Impacts of the COVID-19 pandemic on life of higher education students: A global perspective, Sustainability, vol. 12 , no. 20 , p. $8438,2020$.

[15] W. Bao, COVID-19 and online teaching in higher education: A case study of Peking University, Hum. Behav. Emerg. Technol., vol. 2, no. 2, pp. 113-115, 2020.

[16] E. Yukselturk and S. Bulut, Predictors for student success in an online course, J. Educ. Technol. Soc., vol. 10, no. 2, pp. 71-83, 2007.

[17] V. Abou-Khalil, S. Helou, E. Khalifé, M. A. Chen, R. Majumdar, and H. Ogata, Emergency online learning in low-resource settings: Effective student engagement strategies," Educ. Sci., vol. 11, no. 1, p. 24, 2021. 